Piotr Szczur

KUL, Lublin

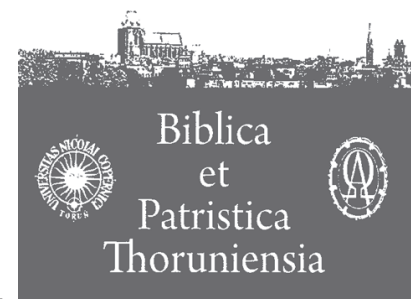

4 (2011) ISSN 1689-5150

\title{
Dzieło stworzenia w Homiliach na Księgę Rodzaju św. Jana Chryzostoma
}

\section{The Work of Creation in John Chrysostom's Homilies on Genesis}

Słowa kluczowe: Jan Chryzostom, Stworzenie, Księga Rodzaju, antropocentryzm.

Key words: John Chrysostom, Creation, Genesis, anthropocentrism.

Księga Rodzaju, a szczególnie biblijny opis dzieła stworzenia (hexaeme(ron), były przedmiotem wielu homilii i komentarzy patrystycznych. Już Teofil z Antiochii (zm. ok. 185) w II księdze apologii Do Autolika podaje alegoryczną interpretację opisu stworzenia świata i człowieka. Z późniejszych zaś serii homilii na temat Księgi Rodzaju należy wymienić napisane w języku greckim Homilie na Ksiegę Rodzaju Orygenesa (zm. ok. 254) ${ }^{2}$, Homilie o sześciu dniach stworzenia Bazylego Wielkiego (ok. 330-379) ${ }^{3}$, oraz Apologię do heksaemeronu $u^{4}$ i stworzeniu człowieka ${ }^{5}$ Grzegorza z Nyssy (ok. 335-395).

1 Ad Autolycum (libri III), ed. G. Bardy: Théophile d'Antioche, Trois livres à Autolycus, [Sources chrétiennes 20], Paris 1948 (dalej: SCh), przekład polski L. Misiarczyk w: Pierwsi apologeci greccy, [Biblioteka Ojców Kościoła 24], s. 385-464.

2 In Genesim homiliae XVI, ed. L. Doutreleau: Origène, Homélies sur la Genèse, SCh $7^{\text {bis }}$, Paris 1976, przekład polski S. Kalinkowski w: Orygenes, Homilie o Księgach Rodzaju, Wyjścia, Kapłańskiej, [Pisma starochrześcijańskich pisarzy 31/1], Warszawa 1984, s. 21-154 (dalej: PSP).

3 Homiliae in hexaemeron, ed. S. Giet: Basile de Césarée, Homélies sur l'hexaéméron, SCh $26^{\text {bis }}$, Paris 1968.

4 Apologia in hexaemeron, PG 44, 61-124.

5 De opificio hominis, PG 44, 124-256, przekład polski M. Przyszychowska w: Grzegorz z Nyssy, O stworzeniu człowieka, [Źródła Myśli Teologicznej 39], Kraków 2006 (dalej: ŹMT). 
Natomiast $\mathrm{z}$ dzieł napisanych $\mathrm{w}$ języku łacińskim warto wymienić Komentarz do Ksieggi Rodzaju przeciw manichejczykom ${ }^{6}$, Niedokończony komentarz słowny do Księgi rodzaju ${ }^{7}$ i Komentarz słowny do Księgi Rodzaju ${ }^{8}$ św. Augustyna (354-430).

Egzegezą Księgi Rodzaju również zajmował się św. Jan Chryzostom (ok. 349-407) ${ }^{9}$, Ojciec i wielki Doktor Kościoła, najwybitniejszy kaznodzieja Kościoła Wschodniego ${ }^{10}$ i jeden $\mathrm{z}$ najsłynniejszych przedstawicieli egzegetycznej szkoły antiocheńskiej, należący do najpłodniejszych pisarzy chrześcijańskich. Jest on autorem dwóch serii homilii na Księgę Rodzaju. Pierwszą serię, składającą się z 8 homilii ${ }^{11}$ opierających się na trzech pierwszych rozdziałach Księgi Rodzaju ${ }^{12}$, nasz autor wygłosił w ro-

6 De Genesi contra Manicheos (libri duo), ed. P. Abulesz: Sancti Aurelii Augustini, De Genesi contra Manicheos (libri duo). De octo quaestionibus ex veteri testamento, Wien 1972, s. 3-114, przekład polski J. Sulowski w: Św. Augustyn, Pisma egzegetyczne przeciw manichejczykom, PSP 25, Warszawa 1980, s. 21-82.

7 De Genesi ad litteram (liber unus imperfectus), ed. J. Zycha: Sancti Aurelii Augustini, De Genesi ad litteram libri duodecim: eiusdem libri capitula. De Genesi ad litteram inperfectus liber. Locutionum in Heptateuchum libri septem, [Corpus scriptorum ecclesiasticorum latinorum 28/1], Vindobonae 1894, s. 459-503 (dalej: CSEL), przekład polski J. Sulowski w: PSP 25, s. 83-112.

8 De Genesi ad litteram (libri XII), ed. J. Zycha: Sancti Aurelii Augustini, De Genesi ad litteram libri duodecim: eiusdem libri capitula. De Genesi ad litteram inperfectus liber. Locutionum in Heptateuchum libri septem, CSEL 28/1, s. 3-435, przekład polski J. Sulowski w: PSP 25, s. 113-382.

9 W literaturze przedmiotu spotyka się różne daty urodzin Jana Chryzostoma. Najczęściej proponowane są lata: 345, 349 oraz 354. Por. A.-M. Malingrey, S. Zincone, Giovanni Crisostomo, w: Nuovo dizionario patristico e di antichità cristiane, red. A. Di Berardino, t. 2, Genova-Milano 2007, kol. 2216.

10 Por. J. Bojarski, Wstęp, w: Św. Jan Chryzostom, Homilie i kazania wybrane, PSP 8, Warszawa 1971, s. 6.

11 Iohannes Chrysostomus, In Genesim, sermones 1-8. Mowy te umieszczone są w Clavis Patrum Graecorum (red. M. Geerard, t. 2, Turnhout 1974, s. 517-518) pod numerem 4410 (dołączona jest do nich jeszcze jedna mowa nosząca numer 9, jednak nie należy ona do wspomnianego cyklu). Wydanie krytyczne tych mów, wraz z przekładem francuskim, przygotował L. Brottier: Jean Chrysostome, Sermons sur La Genése, SCh 433, Paris 1998, s. 138-365; przekład polski S. Kaczmarek w: Jan Chryzostom, Homilie na Księgę Rodzaju (seria pierwsza: Rdz 1-3), ŹMT 45, Kraków 2008.

12 Zagadnienia poruszane w poszczególnych homiliach pokrótce omawia wydawca homilii L. Brottier (Introduction, w: SCh 433, s. 16-17). Szerzej omawia je autorka polskiego przekładu homilii S. Kaczmarek (por. tenże, Egzegeza biblijna $w$ „Homiliach na Ksiege Rodzaju (Rdz 1-3)" św. Jana Chryzostoma, w: ŹMT 45, s. 29-36). 
ku $386^{13}$, niedługo po przyjęciu święceń kapłańskich ${ }^{14}$. Następnie, ok. 388 r. $^{15}$ na temat Księgi Rodzaju wygłosił cykl 67 homilii ${ }^{16}$, które obejmowały całość tej księgi Starego Testamentu.

W homiliach tych na określenie „stworzenia” Jan Chryzostom używa greckiego terminu $\kappa \tau i ́ \sigma 1 \varsigma$, który ma dwa wymiary semantyczne ${ }^{17}$. Jego znaczenie może być aktywne, gdy odnosi się do samego aktu stwórczego, lub pasywne, gdy odnosi się do wyniku tegoż aktu ${ }^{18}$. W niniejszym artykule, bazując na wypowiedziach złotoustego kaznodziei zawartych $\mathrm{w}$ pierwszej serii homilii na Księgę Rodzaju, postanowiono zaprezentować jego naukę na temat dzieła stworzenie, które jest efektem stwórczego działania Boga.

13 Por. Brottier, Introduction, s. 11-12; W. Mayer, The Homilies of St John Chrysostom: Provenance. Reshaping the Foundations, [Orientalia Christiana Analecta 273], Roma 2005, s. 266.

14 Od końca 380 lub początku roku 381, Chryzostom był diakonem. Święceń udzielił mu biskup Melecjusz (por. Palladius, Dialogus de vita Iohannis Chrysostomi 5, ed. A. M. Malingrey, P. Leclercq: Palladios, Dialogue sur la vie de Jean Chrysostome, SCh 341, Paris 1988, s. 110; J. N. D. Kelly, Złote usta. Jan Chryzostom - asceta, kaznodzieja, biskup, przekł. K. Krakowczyk, Bydgoszcz 2001, s. 49; C. Tiersch, Johannes Chrysostomus in Konstantinopel (398-404). Weltsicht und Wirken eines Bischofs in der Hauptstadt des Oströmischen Reiches, [Studien und Texte zu Antike und Christentum 6], Tübingen 2002, s. 60). Na prezbitera został wyświęcony na początku 386 roku, lecz nie wcześniej niż 15 lutego. Odnośnie do daty święceń zob. C. Baur, Der heilige Johannes Chrysostomus und seine Zeit, t. 1: Antiochien, München 1929, s. 180; Brottier, Introduction, s. 11; Kelly, Złote usta, s. 49, 65; Tiersch, Johannes Chrysostomus in Konstantinopel (398-404), s. 60-61.

15 Dokładna data wygłoszenia tego cyklu homilii jest trudna do ustalenia. Uczeni hipotetycznie wyznaczają daty, które mieszczą się w przedziale od 388 do 396 roku [por. C. Baur, Chrysostomus in Genesim, „Theologische Quartalschrift” 108 (1927), s. 221-232], jednak większość wskazuje rok 388 jako czas wygłoszenia homilii (por. Mayer, The Homilies of St John Chrysostom, s. 266).

16 Iohannes Chrysostomus, In Genesim, homiliae 1-67. Homilie te umieszczone są w Clavis Patrum Graecorum (t. 2, s. 517) pod numerem 4409. Zostały one wydane w PG 53, 21-385, 54, 385-580.

17 Zwraca na to uwagę autor najpopularniejszego słownika greki patrystycznej G. W. H. Lampe (por. tenże, A Patristic Greek Lexicon, Oxford 1961, s. 782-783) (dalej: Lampe) oraz redaktorka największego słownika grecko-polskiego Zofia Abramowiczówna [por. Słownik grecko-polski, red. Z. Abramowiczówna, t. 2, Warszawa 1960, s. 724 (dalej: Abramowiczówna 1-4)].

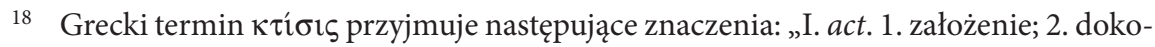
nanie; 3. stworzenie; II. pass. to, co stworzone; 1. świat; 2. stworzenie; ustanowiona władza” (Abramowiczówna 2, s. 724); por. Lampe, s. 782-783; H. G. Liddell, R. Scott, Greek - English Lexicon, Oxford 1958, s. 1003 (dalej: Liddell-Scott). 


\section{Stworzenie człowieka}

Jan Chryzostom zauważa, że Mojżesz ${ }^{19}$, w odniesieniu do rzeczy stworzonych przed człowiekiem, wkłada w usta Boga wyrażenie "niech się stanie ( $\gamma \varepsilon v$ $\eta \theta \eta \omega^{20}$ )" (por. Rdz 1, 3. 6. 14), natomiast w odniesieniu do człowieka, wkłada w usta Boga imperatyw „uczyńmy $\left(\pi \circ \imath \eta ́ \sigma \omega \mu \varepsilon v^{21}\right)$ ” $(\operatorname{Rdz} 1,26)^{22}$. Ta różnica lingwistyczna stała się dla niego podstawą do wyciągnięcia wniosku, że w dzie-

19 Jan Chryzostom jest przekonany, że autorem Księgi Rodzaju jest Mojżesz.

20 Grecki czasownik $\gamma^{\prime} \gamma v o \mu \alpha$ przyjmuje następujące znaczenia: „I. stawać się; 1. o osobach, urodzić się; 2. o rzeczach, powstawać, stawać się, pojawiać się; II. z orzecznikiem, stawać się, zostawać, być kimś, czymś, jakims’” (Abramowiczówna 1, s. 465-467). Por. Lampe, s. 315; Liddell-Scott, s. 349-350.

21 Grecki czasownik $\pi$ oté $\omega$ przyjmuje następujące znaczenia: „I. act. 1. robić, wytwarzać, sporządzać, o czymś materialnym; 2. stworzyć; 3. wytworzyć; 4. tworzyć, komponować, pisać; 5. wynaleźć, wymyślić; 6. sprowadzić, wywołać, spowodować; 7. uzyskać, nastręczyć, sprawić; 8. obchodzić, urządzać, o ofiarach, uroczystościach etc.; 9. $z$ adi. praedicativum uczynić kogoś kimś, jakimś, coś czymś; 10. położyć, włożyć, umieścić; 11. przypuścić, przyjąć, założyć, że z inf.; 12. o czasie, zwlekać; 13. późn. ofiarować; 14. przyrządzić jako potrawę; 15. grać rolę; 16. starać się, zabiegać; czynić, postępować; 17. uprawiać coś; 18. zpodw. acc. uczynić lub wyrządzić komuś coś; 20. być czynnym, działać; medic. być skutecznym, działać na coś; II. med. 1. zrobić sobie, dla siebie; 2. spłodzić; o kobiecie, począć; 3. o wojnie, wypowiedzieć; o pokoju, zawrzeć; 4. uzyskać dla siebie, dostać, osiągnąć; 5. zwoływać, organizować zebranie, uroczystość itp.; 9. poczytywać, uważać coś za coś; 10. o czasie, spędzić, przebyć" (Abramowiczówna 3, s. 567-469). Por. Lampe, s. 1107-1108; Liddell-Scott, s. 1427-1429.

22 Por. Iohannes Chrysostomus, In Genesim, ser. 2, 1, SCh 433, s. 184, ŹMT 45, s. $63-$ 64: „To jedno najpierw warto zbadać: dlaczego mianowicie, kiedy stawało się niebo, nigdzie nie rzecze «Uczyńmy», lecz «Niech się stanie niebo» $(\mathrm{Rdz} 1,6)$ i «Niech się stanie światło» (Rdz 1, 3), i przy każdym elemencie stworzenia podobnie? Tylko tutaj jest «uczyńmy» i naradzanie się, i zamysł, i porozumiewanie się z kimś równym godnością?” Chryzostom uważa, że sformułowanie „uczyńmy (poi»swmen)” (Rdz 1, 26) jest zarezerwowane dla człowieka i wyraża jedność Ojca i Syna; por. Iohannes Chrysostomus, In Genesim, ser. 2, 2, SCh 433, s. 190, ŹMT 45, s. 65: „Kim więc jest ten, do kogo mówi: «Uczyńmy człowieka» (Rdz 1, 26)? «Przedziwny Doradca, dzierżący najwyższą władzę, Bóg potężny, Książę pokoju, Ojciec przyszłego wieku» (por. Iz 9, 5 - Septuaginta podaje nieco uboższą wersję tego wersetu, jednak w niektórych manuskryptach pojawiają się wszystkie z wymienionych tytułów chrystologicznych; SCh 433, s. 191, przypis nr 5), sam jednorodzony Syn Boga. Do Niego mówi: «Uczyńmy człowieka na obraz i podobieństwo nasze» $(\operatorname{Rdz} 1,26)$. Nie powiedział: «mój i twój» albo «mój i wasz», lecz: «na nasz obraz», ujawniając wspólny obraz i jedno podobieństwo”. Por. S. Włodarczyk, Człowiek obrazem Boga według Jana Chryzostoma, „Ruch Biblijny i Liturgiczny” 43 (1990), s. 124; L. Brottier, L’appel des «demi-chrétiens» à la "vie angélique». Jean Chrysostome prédicateur: entre idéal monastique et réalité mondaine, [Patrimoines-Christianisme], Paris 2005, s. 314-315. 
le stworzenia przedstawiony jest Boży plan zbawienia: stworzenie jawi się jako jego początek, a Odkupienie jako jego koniec:

Kimże jest ten, kto ma być stworzony, że tak wielkiej czci doznaje? To jest człowiek: wielka i godna podziwu istota, cenniejsza dla Boga niż cała reszta stworzenia, ze względu na którą istnieje niebo i ziemia, i morze, i każdy element stworzenia; człowiek, którego zbawienia Bóg tak pragnął, że dla niego nie oszczędził (por. Rz 8 , 32) nawet Jednorodzonego. Gdyż Bóg nie ustał, czyniąc wszystko i podejmując starania, dopóki nie wyniósł go i nie posadził na swojej prawicy. [...] To dlatego i naradzanie się, i zamysł, i porozumiewanie się: nie dlatego, iżby Bóg potrzebował naradzania się - w żadnym razie! - lecz przez dobór słów ukazuje nam wartość tego, co zostało stworzone ${ }^{23}$.

Antiocheńczyk podkreśla też, że człowiek został stworzony na obraz i podobieństwo Boga - „na Nasz obraz” (Rdz 1, 26) $)^{24}$ - jak mówi autor natchniony. Jednak sformułowania "na obraz" nie interpretuje w sensie „obrazu istoty”

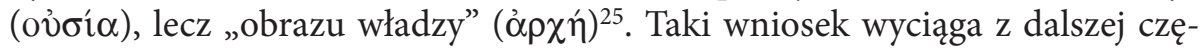
ści interpretowanego wersetu ( $\mathrm{Rdz} 1,26)$, w którym jest mowa o panowaniu człowieka "nad rybami morskimi, nad ptactwem powietrznym, nad bydłem, nad ziemią i nad wszystkimi zwierzętami pełzającymi po ziemi!” $(\operatorname{Rdz} 1,26)^{26}$. Zatem człowiek został wyniesiony ponad inne stworzenia i posiada władzę będącą obrazem władzy Boga ${ }^{27}$.

Wyjaśniając natomiast biblijne wyrażenie „na podobieństwo”, nasz autor podkreśla, że „dotyczy [ono] bycia uległym ( naśladowania w miarę możności Boga w dziedzinie cnoty, jak rzecze Chrystus: «Stawajcie się podobni do Ojca mojego w niebiosach» (Mt 5, 45)"28. Zatem Bóg postawił przed człowiekiem zadanie, aby stawał się do Niego podobny poprzez doskonalenie, opanowywanie złych skłonności i zdobywanie cnót ${ }^{29}$. Chryzostom podkreśla też, że człowiek jest w stanie podjąć ten trud doskonalenia. Stosując porównanie i analogię odwołuje się do tresowania dzikich zwierząt.

23 Iohannes Chrysostomus, In Genesim, ser. 2, 1, SCh 433, s. 184-186, ŹMT 45, s. 64.

24 Por. Iohannes Chrysostomus, In Genesim, hom. 12, 4, PG 53, 102; tamże, hom. 21, 2, PG 53, 177.

25 Por. Włodarczyk, Człowiek obrazem Boga, s. 125.

26 Por. Iohannes Chrysostomus, In Genesim, ser. 2, 2, SCh 433, s. 192; tamże, ser. 3, 1, SCh 433, s. 204.

27 Por. Włodarczyk, Człowiek obrazem Boga, s. 124-125.

28 Iohannes Chrysostomus, In Genesim, ser. 3, 1, SCh 433, s. 204, ŹMT 45, s. 69. Por. Włodarczyk, Człowiek obrazem Boga, s. 125.

29 Por. Iohannes Chrysostomus, In Genesim, hom. 9, 3, PG 53, 78. 
Zauważa, że skoro człowiek potrafi oswoić lwa i przemienić jego naturalną dzikość w przeciwną jego naturze łagodność, to tym bardziej potrafi zapanować nad swoją duszą i usunąć z niej przeciwną jego naturze dzikość i wszczepić łagodność, która jest zgodna z jego naturą ${ }^{30}$. Ci, którzy nie podejmują tego wysiłku objawiają swą gnuśność i lenistwo, tym bardziej, że ludzka dusza otrzymuje wsparcie od zakorzenionej w niej bojaźni Bożej i od rozumu. Podsumowując swe wywody i jednocześnie zachęcając wiernych do podjęcia trudu doskonalenia i stawania się „na podobieństwo” Boga, nasz autor mówi: „Jeśli zechcesz, możesz być uległy i cichy" ${ }^{1}$.

Stworzonego człowieka Bóg obdarował niezwykłą godnością ${ }^{32}$. Jan Chryzostom podkreśla, że nie była to nagroda za dobre czyny, lecz wyraz niezwykłej łaski i wielkiej miłości Boga do człowieka ( $\left.\varphi \imath \lambda \alpha v \theta \rho \omega \pi^{i} \alpha^{33}\right)$. Odwołując się do życia codziennego, nasz autor zauważa, że władcy ziemscy nadają swym poddanym różne godności i przywileje dopiero wtedy, gdy zdobędą odpowiednie zasługi i osiągną podeszły wiek. Natomiast Bóg nie czekał, aż człowiek zdobędzie zasługi, lecz zaraz po stworzeniu obdarował go wielką godnością ${ }^{34}$.

Człowiek został stworzony jako władca ustanowiony do rządzenia wszystkimi stworzeniami (por. Rdz 1,26). W tym kontekście Jan Chryzostom odpiera

30 Por. Iohannes Chrysostomus, In Genesim, ser. 3, 1, SCh 433, s. 206, ŹMT 45, s. 6970: „Poddajemy sobie lwy i oswajamy ich duszę, a wątpisz, czy mógłbyś przemienić dzikość rozumu w łagodność? Przecież lwa z natury cechuje okrucieństwo, wbrew zaś naturze uległość; w twoim natomiast przypadku odwrotnie: zgodna z naturą jest łagodność, przeciwna zaś naturze jest dzikość. Ten zatem, kto usuwa z duszy zwierzęcia to co zgodne $\mathrm{z}$ naturą, a to co przeciwne naturze weń wszczepia, nie mógłby zachować we własnej duszy tego, co jest zgodne z naturą?"

31 Iohannes Chrysostomus, In Genesim, ser. 3, 1, SCh 433, s. 208, ŹMT 45, s. 70.

32 Chryzostom wyraźnie naucza, że przed popełnieniem grzechu przez pierwszych rodziców, mężczyzna i niewiasta mieli jednakową godność. Dopiero po grzechu niewiasta została poddana mężczyźnie. Por. Iohannes Chrysostomus, In Genesim, ser. 4, 1, SCh 433, s. 222-224, ŹMT 45, s. 74-75: „Przed nieposłuszeństwem niewiasta była przecież równa w godności mężczyźnie [...]. Tak było przed grzechem, natomiast po grzechu: «Ku mężowi twemu twoje skierowanie, a on będzie nad tobą panował» $(\operatorname{Rdz} 3,16)$. «Uczyniłem cię powiada - równą w godności. Nie użyłaś w dobry sposób władzy, przejdź w poddaństwo. Nie uniosłaś ciężaru wolności, przyjmij niewolę. Nie umiałaś panować i dałaś tego dowód w konkretnej próbie, bądź zatem wśród rządzonych i uznaj w mężczyźnie pana»”.

33 Grecki rzeczownik $\varphi \imath \lambda \alpha \nu \theta \rho \omega \pi i \alpha$ przyjmuje następujące znaczenia: „1. ludzkość, życzliwość, ludzkie uczucia; stosunki wzajemne kochanków; pl. akty uprzejmości, grzeczności; miłość Boga do ludzi; 2. o rzeczach, łagodność; cywilizacja; złagodzenie choroby, ulga, lekka poprawa $w$ chorobie" (Abramowiczówna 4, s. 515-516). Por. Lampe, s. 1475-1476; Liddell-Scott, s. 1932.

34 Por. Iohannes Chrysostomus, In Genesim, ser. 4, 1, SCh 433, s. 220. 
zarzuty pogan, którzy twierdzili, że to zdanie Księgi Rodzaju jest fałszywe, gdyż człowiek w gruncie rzeczy nie panuje nad dzikimi zwierzętami, lecz to one panują nad nim, a niekiedy nawet atakują go. Wyjaśnia, że rozumowanie pogan nie jest właściwe, gdyż „wystarczy przecież samo ludzkie spojrzenie, by dzikie zwierzę trzymało się z dala, tak wielka jest ich bojaźń wobec nas"35. Natomiast jeśli dzikie zwierzę zaatakuje człowieka, to nie jest to wyraz jego panowania nad człowiekiem, lecz podjęcia środków dla własnego ocalenia ${ }^{36}$. Przyznaje wprawdzie, że człowiek odczuwa lęk przed dzikimi zwierzętami, jednak twierdzi, że tak nie było od początku: to „dzikie zwierzęta bały się człowieka i drżały przed nim, i były mu poddane jak panu" ${ }^{37}$. Na poparcie swej tezy złotousty kaznodzieja przytacza dwa argumenty. Pierwszym jest tekst z Księgi Rodzaju, w którym jest mowa o tym, że Bóg przyprowadził do Adama wszelkie zwierzęta, aby zobaczyć, jak je nazwie (por. Rdz 2, 19). Jest rzeczą ważną - mówi Chryzostom - że „Adam nie uskoczył, jakby odczuwał lęk, lecz nadał wszystkim imiona jak podwładnym niewolnikom"38. Drugim natomiast jest opowiadanie o grzechu pierwszych rodziców, a konkretnie - rozmowa węża z Ewą (por. Rdz 3, 1-5). Chryzostom twierdzi, że „gdyby zwierzęta budziły trwogę w ludziach, na widok węża niewiasta nie pozostałaby na miejscu, lecz by uciekła. Nie przyjęłaby rady, nie rozmawiałaby $z$ nim $w$ tak wielkim poczuciu bezpieczeństwa, lecz przerażona jego widokiem natychmiast by uciekła. A tu i rozmawia, i nie boi się; gdyż ów lęk nie istniał”39. Dopiero po popełnieniu grzechu przez pierwszych rodziców, gdy człowiek stracił swobodny przystęp do Boga, godność i władzę ${ }^{40}$, zaczął odczuwać lęk przed dzikimi zwierzętami ${ }^{41}$. Swe sta-

35 Iohannes Chrysostomus, In Genesim, ser. 3, 2, SCh 433, s. 208, ŹMT 45, s. 70.

36 Por. Iohannes Chrysostomus, In Genesim, ser. 3, 2, SCh 433, s. 208.

37 Iohannes Chrysostomus, In Genesim, ser. 3, 2, SCh 433, s. 210, ŹMT 45, s. 70-71. Por. tamże, ser. 4, 1, SCh 433, s, 218.

38 Iohannes Chrysostomus, In Genesim, ser. 3, 2, SCh 433, s. 210, ŹMT 45, s. 71. Por. tamże, ser. 5, 2, SCh 433, s. 264. W starożytności istniał zwyczaj nadawania niewolnikom nowych imion w momencie ich zakupu, co było zademonstrowaniem otoczeniu i niewolnikowi władzy pana; por. Iohannes Chrysostomus, In Genesim, hom. 14, 5, PG 53, 116.

39 Iohannes Chrysostomus, In Genesim, ser. 3, 2, SCh 433, s. 210-212, ŹMT 45, s. 71.

40 Por. Iohannes Chrysostomus, In Genesim, ser. 4, 1, SCh 433, s. 220.

41 Jan Chryzostom zauważa, że w życiorysach niektórych postaci biblijnych obecne są epizody poświadczające ich realną władzę nad dzikimi zwierzętami, której źródłem była ich świętość. Jako przykłady przywołuje postaci Daniela i św. Pawła; por. Iohannes Chrysostomus, In Genesim, ser. 5, 2, SCh 433, s. 264, ŹMT 45, s. 86: „Niegdyś w Babilonii wtrącono Daniela do jaskini. Lwy nie ważyły się go jednak tknąć (por. Dn 6). Dostrzegły jaśniejący w nim dawny, królewski obraz; zobaczyły te same cechy, które widziały w Adamie, zanim zgrzeszył. Przecież w stanie takiego poddaństwa przyszły do Adama, kiedy to otrzymywały imiona (por. 
nowisko Antiocheńczyk uzasadnia w następujący sposób: „Dopóki [człowiek] miał swobodny przystęp ( $\pi \alpha \rho j \rho ́ \eta \sigma i \alpha \nu)$ do Boga, zwierzęta się go bały; gdy się z Nim zwaśnił, w konsekwencji zaczął się bać nawet ostatnich z współsług"42.

$\mathrm{W}$ fakcie, że po popełnieniu grzechu przez pierwszych rodziców, Bóg nie pozbawił ich całkowicie nadanej im wcześniej godności i władzy, Chryzostom dostrzega miłosierdzie ( $\varphi \imath \lambda \alpha \nu \theta \rho \omega \pi i \alpha)$ Boga względem człowieka. Zauważa, że spod władzy człowieka Bóg zwolnił tylko te zwierzęta, które i tak nie były mu zbyt pomocne; natomiast te zwierzęta, które dla człowieka są użyteczne, Bóg pozostawił w jego władaniu ${ }^{43}$. Bóg tak uczynił gdyż chciał, aby kara nałożona na człowieka, polegająca na konieczności zdobywaniu pożywienia w pocie czoła (por. Rdz 3, 19), nie była dla niego nie do zniesienia, i aby zwierzęta pomagały człowiekowi w trudzie i ciężkiej pracy wyciskającej pot.

Chryzostom twierdzi, że Adam był obdarowany wielką mądrością i już przed popełnieniem grzechu posiadał zdolność rozróżniania dobra i zła ${ }^{44} \cdot \mathrm{Na}$ potwierdzenie swej tezy przytacza aż pięć argumentów: 1) gdyby tak nie było, to Adam byłby „najlichszy ze wszystkich” 45 i „bardziej nierozumny od nierozumnych istot" ${ }^{36}$, które doskonale wiedzą, jakie rośliny mogą jeść, a jakich nie mogą, i co jest dla nich dobre, a co złe ${ }^{47}$, a przecież jest od nich doskonalszy ${ }^{48}$;

Rdz 2, 19-20). I nie był to jedyny przykład, bo i błogosławionemu Pawłowi to się przydarzyło. On to, wyrzucony jako rozbitek na brzeg wyspy barbarzyńców, usiadł przy ogniu, grzejąc się; a wtedy z suchych gałęzi wyskoczyła żmija i dosięgła jego ręki (por. Dz 28, 3). I co się potem stało? Zwierzę natychmiast spadło. Skoro nie znalazło grzechu, nie było w stanie ukąsić".

42 Iohannes Chrysostomus, In Genesim, ser. 3, 2, SCh 433, s. 212, ŹMT 45, s. 71.

43 Por. Iohannes Chrysostomus, In Genesim, ser. 3, 2, SCh 433, s. 214, ŹMT 45, s. 72: „Pozostawił stada wołów, abyśmy ciągnęli pług, abyśmy orali ziemię, abyśmy wysiali ziarna; pozostawił gatunki jucznego bydła, aby nam towarzyszyły $\mathrm{w}$ trudach związanych $\mathrm{z}$ transportem towarów; pozostawił trzody owiec, abyśmy dzięki nim mieli wystarczające zaopatrzenie w płaszcze do okrycia się; pozwolił też pozostać innym jeszcze gatunkom zwierząt, które przynoszą nam wiele pożytku”.

44 Por. Iohannes Chrysostomus, In Genesim, ser. 6, 1, SCh 433, s. 286; tamże, ser. 7, 2, SCh 433, s. 310. 316; tamże, ser 8, 1, SCh 433, s. 348.

45 Iohannes Chrysostomus, In Genesim, ser. 6, 1, SCh 433, s. 288, ŹMT 45, s. 93.

46 Iohannes Chrysostomus, In Genesim, ser. 6, 1, SCh 433, s. 286, ŹMT 45, s. 92.

47 Por. Iohannes Chrysostomus, In Genesim, ser. 6, 1, SCh 433, s. 286-288, ŹMT 45, s. 92-93: „Czy nie byłoby niedorzecznością, że kozy i owce wiedzą, jakie rośliny są dla nich zdatne, a jakie zgubne, i że nie podchodzą do wszystkiego, co tylko zobaczą, lecz mają zdolność rozpoznawania i dobrze wiedzą, co jest dla nich szkodliwe, a co korzystne, natomiast człowiek byłby pozbawiony takiej pewności?"

48 Iohannes Chrysostomus, In Genesim, ser. 6, 1, SCh 433, s. 288, ŹMT 45, s. 93: „Tym różnimy się właśnie od bezrozumnych istot i dzięki temu jesteśmy lepsi od zwierząt, że wiemy, czym jest nieprawość i cnota, rozpoznajemy zło i dobra nie jesteśmy nieświadomi”. 
2) skoro obecnie - po popełnieniu grzechu przez pierwszych rodziców - ludzie posiadają zdolność rozróżniania dobra i zła, niezależnie od tego czy są Hellenami, czy barbarzyńcami, to tym bardziej Adam posiadał tę zdolność przed grzechem; człowiek, który został uhonorowany i wyróżniony przez stworzenie na obraz i podobieństwo Boga (por. Rdz 1,26) oraz obdarowany rozmaitymi błogosławieństwami, „nie mógł nie posiadać głównego dobra”49, którym jest poznanie dobra i zła; zdolności rozróżniania dobra i zła nie posiadają tylko ci, którzy są pozbawieni rozumu, a przecież Adam był napełniony wielką mądrością, gdyż umiał nadać imiona wszystkim zwierzętom (por. Rdz 2, 19-20), i z tego względu musiał posiadać tę zdolność ${ }^{50}$; 3) Adam był obdarowany wielką mądrością, gdyż zauważył, że Ewa jest istotą jemu równą, a ujrzawszy ją, "natychmiast rozpoznał w niej uczestniczkę swej natury" ${ }^{51}$ oraz że nie należy ona do grupy stworzeń, które Bóg wcześniej przyprowadził do niego; 4) gdyby dopiero po popełnieniu grzechu człowiek zdobył zdolność rozróżniania dobra i zła, to „grzech byłby dla niego nauczycielem mądrości, a wąż nie byłby zwodzicielem, lecz pożytecznym doradcą ${ }^{52}$, bo ze zwierzęcia uczyniłby go człowiekiem" ${ }^{33}$; 5) gdyby człowiek nie posiadał zdolności rozróżniania dobra i zła, to nie mógłby otrzymać od Boga przykazania zakazującego spożywania owoców z drzewa poznania dobra i zła, a także nie mógłby zostać ukarany za naruszenie tego zakazu, gdyż prawa są dawane tylko tym, którzy wiedzą, że ich przekroczenie jest złem, za które grozi kara ${ }^{54}$.

Z przedstawionych powyżej treści jednoznacznie wynika, że człowiek w nauczaniu Jana Chryzostoma - znajduje się w centrum stworzenia, gdyż ze względu na niego Bóg stworzył cały świat. Ponadto człowiek został stworzony

49 Iohannes Chrysostomus, In Genesim, ser. 6, 1, SCh 433, s. 288-290, ŹMT 45, s. 93.

50 Por. Iohannes Chrysostomus, In Genesim, ser. 6, 1, SCh 433, s. 288-290, tamże, ser. 7, 2, SCh 433, s. 310.

51 Iohannes Chrysostomus, In Genesim, ser. 6, 1, SCh 433, s. 290, ŹMT 45, s. 93.

52 W starożytności istniała sekta gnostycka (ofici), która w swym nauczaniu eksponowała postać węża jako pierwszego przekaziciela gnozy, w tym rozeznawania dobra i zła. Por. A. Zmorzanka, Ofici, w: Powszechna encyklopedia filozofii, t. 7, Lublin 2006, s. 774-776; C. Gianotto, Ofiti-Naasseni, w: Nuovo dizionario patristico e di antichità cristiane, t. 2, red. A. Di Berardino, Genova - Milano 2007, kol. 3588-3590; A. Zmorzanka, Ofici, w: Encyklopedia katolicka, t. 14, Lublin 2010, kol. 404-405.

53 Iohannes Chrysostomus, In Genesim, ser. 6, 2, SCh 433, s. 294, ŹMT 45, s. 94; por. tamże, ser. 8, 1, SCh 433, s. 348.

54 Por. Iohannes Chrysostomus, In Genesim, ser. 6, 2, SCh 433, s. 294, ŹMT 45, s. 94: „Bóg zaś dał prawo, a przekraczającego je ukarał. Ani jednego, ani drugiego nie uczyniłby, gdyby od początku nie stworzył człowieka zdolnym rozeznawać cnotę i nieprawość"; tamże, ser. 7, 2, SCh 433, s. 312. 
na obraz i podobieństwo Boga, co nasz autor rozumie jako obdarowanie władzą i zdolnością naśladowania Boga „w dziedzinie cnoty”, oraz otrzymał niezwykłą godność i mądrość.

\section{Dzieło stworzenia jako „spektakl”}

Specyficznym wymiarem chryzostomowej prezentacji dzieła stworzenia jest traktowanie go jako pewnego rodzaju „widowiska” lub „spektaklu”, który został przygotowany przez Boga dla człowieka po to, aby ów odkrył w stworzonych dziełach Bożą moc, potęgę i chwałę. Zatem dzieło stworzenia jest nieustanną katechezą, która ma prowadzić człowieka do Boga ${ }^{55}$.

W homiliach na Księgę Rodzaju Antiocheńczyk zachęcał swoich słuchaczy do osobistej medytacji dzieła stworzenia, która była przez niego przedstawiana jako wewnętrzny, duchowy dialog z Bogiem. Właściwe prowadzenie tego dialogu z pewnością doprowadzi do poznania Stwórcy. Ten motyw spotkania z dziełem stworzenia ukierunkowanym na zbawienie człowieka wielokrotnie pojawia się w homiliach Chryzostoma. Można w nim dostrzec krzyżowanie się dwóch innych idei: 1) samowystarczalności Boga, który nie potrzebował dla siebie wspaniałego wszechświata, a jedynym powodem stworzenia go była Jego miłość do człowieka, którego chciał umieścić w centrum stworzenia; 2) wielkiej mocy Słowa Bożego, które jest niewidzialne, lecz skuteczne, zaś ziemskie ślady Jego obecności i skutecznej działalności powinny zachęcać i zapraszać ludzi do odnajdywania Go i zatapiania się w Nim przez kontemplację.

Jednak Chryzostom w kontemplacji wielkości i piękna dzieła stworzenia dostrzegał też pewne niebezpieczeństwo, które wiązało się z tym, że człowiek kontemplując stworzenie mógł nie dojść do poznania Stwórcy, lecz zatrzymać się na podziwie dla samego stworzenia, a w konsekwencji ubóstwić je ${ }^{56}$. Z tego względu w homiliach na temat Księgi Rodzaju, Jan Chryzostom stara się rozwiać wszelkie ewentualne wątpliwości dotyczące istoty stworzenia i jego Stwórcy oraz pomyłki pomiędzy stworzeniem i Stwórcą:

55 Por. L. Brottier, La lecture chrysostomienne des deux premiers chapitres de la «Genèse»: une création ordonnée et offerte en spectacle à l'homme, "Connaissance des Pères de l'Église” 84 (2001), s. 26-27.

56 Literatura mądrościowa Starego Testamentu również zwracała na to uwagę. Por. Mdr 13, 1: „Głupi z natury są wszyscy ludzie, którzy nie poznali Boga z dóbr widzialnych nie zdołali poznać Tego, który jest, patrząc na dzieła, nie poznali Twórcy”. 
«A czy i nas - powiada - dotyczy opowiadanie o stworzeniu?» Właśnie nas dotyczy, umiłowany. Jeśli bowiem «poprzez wielkość i piękno stworzeń odpowiednio kontempluje się stwórcę» (Mdr 13, 5), w takim razie: w jak wielkim stopniu poświęcimy czas pięknu i wielkości stworzeń, w tak wielkim stopniu zostaniemy poprowadzeni do Stwórcy. Wielkim jest dobrem wiedzieć: czym jest stworzenie,

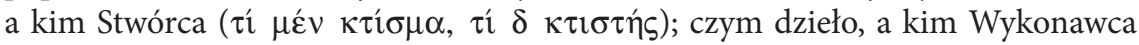

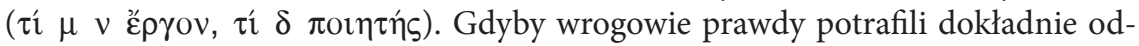
różnić jedno od drugiego, nie pomieszaliby wszystkiego przestawiając to, co jest na dole, $\mathrm{z}$ tym, co jest na górze; nie w tym sensie, iżby gwiazdy i niebo ściągnęli na dół, a ziemię wynieśli do góry, lecz w tym, że Króla niebios sprowadzili z tronu królewskiego i postawili razem ze stworzeniem, stworzeniu zaś przyznali pierwsze miejsce, należne bóstwu. [...] Po to niebo jest piękne, abyś oddał pokłon temu, kto je stworzył; po to słońce jest świetliste, abyś był pełen uszanowania dla jego wykonawcy; jeśli zaś chcesz pozostawać w podziwie dla stworzenia i zatrzymać się na pięknie dzieł: światło stało ci się mrokiem [por. Hi 22, 11; Iz 59, 9 (LXX); Mt 6, 23], a raczej posłużyłeś się nim, by wejść w mrok $^{57}$.

Powyższa wypowiedź jednoznacznie dowodzi, że już w pierwszej homilii na temat Księgi Rodzaju, czyli praktycznie od początku swej działalności kaznodziejskiej, Antiocheńczyk wykazywał troskę o to, by z wielką przejrzystością wytłumaczyć wiernym zasadniczą różnicę istniejącą pomiędzy stworzeniem a Stwórcą, wyjaśnić nieporozumienia w tym względzie i zachęcić słuchaczy do zrozumienia i przyjęcia właściwej hierarchii bytów. Chodziło mu o to, aby każdy chrześcijanin potrafił przejść od kontemplacji Bożego daru, którym jest stworzony świat, do poszukiwania pierwotnego źródła tego daru - do Boga. Chryzostom zdawał sobie sprawę z tego, że podziwianie stworzonego świata zamiast Boga, który go powołał do istnienia, jest zupełnym wypaczeniem Bożej pedagogii i odejściem od jej właściwego celu. Z tego względu bardzo mocno akcentował ostateczny cel kontemplacji stworzonego świata, którym jest poznanie jego Stwórcy. Przedstawiając „porządek rzeczy” nasz autor nauczał, że podziwianie stworzenia jest tylko jednym $z$ etapów na drodze prowadzącej do właściwego celu, którym jest poznanie Boga.

Złotousty kaznodzieja podkreśla, że ten, kto jest oszołomiony podziwem dla stworzonego świata, jest zagrożony bałwochwalstwem, do którego może go nakłonić zachwyt nad dziełami stworzonymi przez Boga. W tym kontekście Antiocheńczyk zauważa, że kolejnym znakiem troski Boga o człowieka jest umieszczenie go w centrum - wprawdzie godnego podziwu, lecz przecież niedoskonałego - świata stworzonego. Według naszego autora takie „postępowanie” Boga jest daniem człowiekowi szansy i możliwości ucieczki z pułapki

57 Iohannes Chrysostomus, In Genesim, ser. 1, 1, SCh 433, s. 142-144, ŹMT 45, s. 52-53. 
bałwochwalstwa. W tym też duchu Chryzostom wyjaśnia początkowe słowa Księgi Rodzaju $(1,2)$ :

«A ziemia była niewidzialna i nieukształtowana» (por. Rdz 1, 2). Dlaczego niebo stworzył jako dokończone, ziemię zaś - jak opisuje Mojżesz - stopniowo wytwarza? Po to, abyś dowiedziawszy się, że moc nieba opiera się na lepszym elemencie, był przekonany, że mógł tak jak niebo, tak i ziemię stworzyć jako ukończoną. Dla ciebie jednak, i dla twojego zbawienia nie uczynił tak. «Jak to: dla mnie i dla mojego zbawienia?» - powiada. Ziemia jest wspólnym stołem i ojczyzną, i żywicielką, i matką wszystkich; jest i miastem, i grobem wspólnym. Ponieważ z niej są nasze ciała, od niej pokarm dla naszych ciał, na niej zamieszkanie i przebywanie, a po śmierci do niej znów powrót. Aby konieczność korzystania z niej nie przywiodła cię do nadmiernego dla niej podziwu i żeby mnóstwo dobrodziejstw nie popchnęło cię do bezbożności, pokazuje ci, że zanim powstała, była bezkształtna i nie uformowana, abyś poznawszy jej niemoc podziwiał Tego, kto ją wytworzył i kto całą jej moc w nią położył; abyś oddawał chwałę Temu, który tak wiele przygotował, by przynieść nam ulgę $e^{58}$.

Zatem Bóg - jak naucza Antiocheńczyk - przez stworzony świat objawia się człowiekowi. Przez kontemplację piękna i wielkości stworzenia człowiek powinien odkryć moc Boga, który uczynił tak wspaniały świat. Dlatego złotousty kaznodzieja przestrzega swych słuchaczy przed nadmiernym zachwytem nad stworzonym światem, a w szczególności przed ubóstwieniem elementów natury. Wyjaśnia, że na początku ziemia była „bezładem i pustkowiem” (Rdz 1, 1), a swój ostateczny kształt uzyskała tylko i wyłącznie dzięki mocy Boga, który z troski o człowieka i z miłości do niego, z wielką mądrością ją urządził i „całą jej moc w nią położył”.

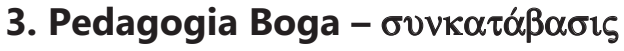

Jan Chryzostom przystępując do objaśniania Księgi Rodzaju podkreśla, że

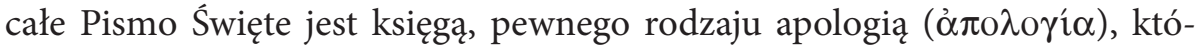
rą Bóg przekazał człowiekowi ${ }^{59}$, aby przez jej właściwe odczytywanie poznał Go i zdobył argumenty zdolne obalić błędne poglądy obecne w religii pogan

58 Iohannes Chrysostomus, In Genesim, ser. 1, 3, SCh 433, s. 166-168, ŹMT 45, s. 58.

59 Por. Iohannes Chrysostomus, In Genesim, ser. 1, 1, SCh 433, s. 146, ŹMT 45, s. 53 54: „Bóg ułożył bowiem apologię na ten [tj. właściwego rozumienia dzieła stworzenia] i wiele innych tematów, i tę księgę nam posłał". 
i nauczaniu heretyków ${ }^{60}$. Przekazanie ludziom przez Boga Pisma Świętego było wyrazem Jego pedagogii, gdyż Pismo było potrzebne człowiekowi, który przez grzech utracił zdolność bezpośredniego komunikowania się z Bogiem $^{61}$. W ten sposób Bóg „zniżył się" do ludzi ${ }^{2}$ i dostosował do ludzkiej mentalności ${ }^{63}$.

60 Przykładowo, odnosząc się do manichejczyków, Chryzostom podkreśla wagę stwierdzenia zawartego już w pierwszym wersecie Pisma Świętego (tj. Rdz 1, 1) i wyjaśnia: „Zdanie jest krótkie i proste, i jest to jedno zdanie, a będzie mogło pokonać wszystkie szyki wrogów. Pomyśl tylko. Podchodzi manichejczyk i mówi, że «materia jest nie stworzona». Powiedź mu: «Na początku Bóg stworzył niebo i ziemię» (Rdz 1, 1) i od razu zburzyłeś całą jego dumę. Nie wierzy jednak zdaniu Pisma. A zatem niczym szalonego przepędź go z tego powodu i odwróć się od niego. Czy nie daje przez niedowiarstwo dowodu oczywistego szaleństwa ten, kto nie wierzy objawiającemu się Bogu i zarzuca fałsz prawdzie?" (Iohannes Chrysostomus, In Genesim, ser. 1, 2, SCh 433, s. 156-158, ŹMT 45, s. 56). Podobne wskazania Chryzostom daje wiernym w odniesieniu do poglądów zwolenników Marcjona i Walentyna (por. Iohannes Chrysostomus, In Genesim, ser. 1, 3, SCh 433, s. 164).

61 Por. Iohannes Chrysostomus, In Genesim, ser. 1, 2, SCh 433, s. 148-150, ŹMT 45, s. 54: „Na początku Bóg sam komunikował się z ludźmi na ile ludzie mogli to pojąć. Tak przybył do Adama (por. Rdz 3, 9), tak skarcił Kaina (por. Rdz 4, 9-15), tak rozmawiał z Noem (por. Rdz 7, 1-4), tak gościł u Abrahama (por. Rdz 18). Skoro jednak nasza natura zboczyła ku złu i oddaliła się niczym do dalekiego kraju wygnania, wówczas do tych, którzy byli daleko, na obczyźnie, Bóg posyła pismo, jakby chciał za pośrednictwem listu odnowić dawną przyjaźń z nami. Pismo to wysłał Bóg, dostarczył zaś Mojżesz".

62 Por. R. A. Krupp, Shepherding the Flock of God. The Pastoral Theology of John Chrysostom, New York 1991, s. 71: „He [John Chrysostom - P. Sz.] viewed them [the Scriptures - P. Sz.] as an example of divine condescension...” Na temat Chryzostomowej teorii „zniżania się” Boga do ludzi w Piśmie Świętym istnieje wyczerpująca monografia: M. H. Flanagan, Chrysostom on the Condescension and Accuracy of the Scriptures, która jest rozprawą doktorską obronioną w 1946 r. w St. Patrick's College w Maynooth, a opublikowaną w Wellington w 1948 r. Zob. też: M. Moro, La condiscendenza divina in S. Giovanni Crisostomo, „Euntes Docete” 11 (1958), s. 109-123; K. Duchatelez, La "condescendance» divine et l'histoire du salut, „Nouvelle Revue Théologique” 6 (1973), s. 593-621; S. Włodarczyk, Rola synkatabasis w interpretacji Pisma św. według św. Jana Chryzostoma, „Ruch Biblijny i Liturgiczny” 27 (1974), s. 246-251; S. Leanza, L'intervento di Dio nella storia secondo la dottrina crisostomica della condiscendenza divina, „Augustinianum” 16 (1976), s. 125-134; B. de Margerie, Saint Jean Chrysostome, docteur de la condescendance biblique, w: Introduction à l'histoire de l'exégèse, t. 1: Les Pères grecs et orientaux, Paris 1980, s. 214-239.

63 Ten pogląd Antiocheńczyka przeciwstawny jest zasadom egzegezy aleksandryjskiej, której główny przedstawiciel - Orygenes - mówił, że Bóg nie zniża się do ludzi, lecz człowiek, przy interpretacji Pisma Świętego, powinien wznieść się ku Bogu. Por. Włodarczyk, Rola synkatabasis, s. 249. 
Na określenie owego „zniżania się” Boga Antiocheńczyk używa greckiego terminu $\sigma v \gamma \kappa \alpha \tau \alpha \dot{\beta} \beta \alpha \iota^{64} \varsigma^{64}$ Chryzostomowa koncepcja „zniżania się" lub „dostosowywania się" Boga do mentalności ludzkiej doprowadziła niektórych uczonych do przypuszczenia, że dostrzegał on w tekście Pisma Świętego skazy i niedoskonałości ${ }^{65}$. Jednak analiza wypowiedzi złotoustego kaznodziei, w których używa terminu $\sigma v \gamma \kappa \alpha \tau \alpha \dot{\beta} \alpha \sigma \imath \varsigma$, jednoznacznie wskazuje, że nie miał on na myśli „niedoskonałości” Pisma, lecz „troskę" i „łaskawość” Boga względem człowieka $^{66}$. Chryzostom stosował rzeczownik $\sigma v \gamma \kappa \alpha \tau \alpha \dot{\beta} \beta \alpha \sigma ı \varsigma$ na określenie działania Boga w stosunku do całej ludzkości, które polegało na docieraniu do ludzi wtedy, gdy tego potrzebowali. Owo „zniżenie się” Boga było konieczne z powodu ludzkiej kondycji duchowej. Dla Antiocheńczyka był to też jeden z najważniejszych znaków miłości Boga do człowieka ${ }^{67}$.

Przekazany przez Boga, za pośrednictwem Mojżesza, opis stworzenia świata, rozpoczyna się od opowiadania o stworzeniu elementów natury: nieba i ziemi (por. Rdz 1, 1). W tym kontekście złotousty kaznodzieja zastanawia się dlaczego opowiadanie to nie rozpoczyna się od opisu stworzenia aniołów i archaniołów? Przecież przez kontemplację bytów doskonalszych - kontynuuje swe dywagacje - człowiek szybciej doszedłby do poznania Boga ${ }^{68}$. Wyjaśniając zaś te wątpliwości Chryzostom podkreśla, że w porządku stworzenia przedstawionym w Księdze Rodzaju zawarte są elementy pedagogii Boga, który

64 Termin $\sigma v \gamma \kappa \alpha \tau \alpha ́ \beta \alpha \sigma ı \varsigma$ przyjmuje następujące znaczenia: „zniżenie się, przystępność; o bóstwach, łaskawość" (Abramowiczówna 4, s. 131). Por. Lampe, s. 1267-1268: "1. descent; 2. resort to, association with; 3. accomodation; a. in respect of laws, customs, leniency, concession; b. in human relationships deference, consideration; c. in respect of one statemen with another, agreement, correspondence; d. in respect of truth, diplomacy; reserve; e. on part of God, accomodation, concession to human limitations; 4. condescension of God"; Liddell-Scott, s. 1662: „condescension to the level of an audience; also of the gods”.

65 Por. F. Fabbi, La condiscendenza divina nell'ispirazione Biblica secondo S. Giovanni Crisostomo, „Biblica” 14 (1933), s. 330-347; R. C. Hill, On Looking Again at «synkatabasis», „Prudentia” 13 (1981), s. 3-11; Y. Congar, Lay People in the Church, London 1985, s. 55; R. C. Hill, Introduction, w: St John Chrysostom, Homilies on Genesis 1-17, [The Fathers of the Church 74], Washington DC 1986, s. 17; Krupp, Shepherding the Flock of God, s. 71.

66 Por. Hill, Introduction, s. 17-19, gdzie autor proponuje, by słowo $\sigma v \gamma \kappa \alpha \tau \alpha \dot{\beta} \alpha \sigma ı \varsigma$ tłumaczyć jako „considerateness”. Wydaje się zatem, że termin „troska” lub „łaskawość”, lepiej oddają myśl Chryzostoma.

67 Należy zaznaczyć, że Chryzostomowa teoria $\sigma v \gamma \kappa \alpha \tau \alpha ́ \beta \alpha \sigma ı \varsigma$ została przyjęta przez Ojców Soboru Watykańskiego II, którzy w Konstytucji dogmatycznej o Objawieniu Bożym odwołują się do wypowiedzi Antiocheńczyka (por. Dei verbum 13).

68 Por. Iohannes Chrysostomus, In Genesim, ser. 1, 2, SCh 433, s. 150, ŹMT 45, s. 55: "Jeżeli do kontemplacji Stwórcy (por. Mdr 13, 5) dochodzi się poprzez stworzenia, to poprzez aniołów o wiele wyraźniej się On objawi”. 
dostosował się do mentalności odbiorców Pisma Świętego - Żydów, „do mniej duchowo usposobionych, żywiących namiętność wobec tego, co zmysłowe, powracających właśnie z Egiptu, gdzie ludzie czcili krokodyle, psy i małpy"69.

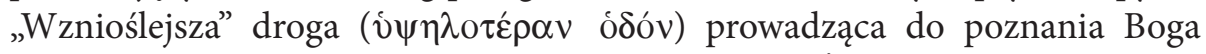
przez kontemplację aniołów i archaniołów, była dla Żydów zbyt „kamienista, niewygodna i nazbyt stroma"70. $\mathrm{Z}$ tego względu Bóg wybrał drogę łatwiejszą,

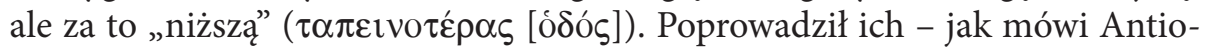
cheńczyk - „przez niebo, ziemię, morze i przez całe widzialne stworzenie”71. Ponadto kaznodzieja podkreśla, że wyrazem miłości i troski o człowieka oraz dostosowywania się Boga do właściwości ludzkiej natury było nadanie Prawa w postaci przykazania danego Adamowi: „Z każdego drzewa w raju możesz spożywać $(\operatorname{Rdz} 2,17)$ ”72. Zatem „zniżanie się" Boga ku człowiekowi w różnych sytuacjach opisanych w księgach Pisma Świętego ma różny charakter, jednak przyświeca mu jeden cel - jest nim miłosierne poszukiwanie człowieka, aby go doprowadzić do łączności ze Stwórcą, a w konsekwencji zbawić go ${ }^{73}$.

\section{Antropocentryzm dzieła stworzenia}

Zaprezentowane powyżej analizy skłaniają do wniosku, że w homiliach na Księgę Rodzaju Jan Chryzostom w sposób bardzo specyficzny prezentuje dzieło stworzenia ${ }^{74}$. Specyfika ta polega na tym, że nie koncentruje się on na opisie szczegółów i detali stwarzanych przez Boga elementów natury, zwierząt i rzeczy, ani nie zadaje licznych pytań natury filozoficznej ${ }^{75}$ - jak czyni to np. Bazyli Wielki w Homiliach o sześciu dniach stworzenia lub Grzegorz z Nyssy w Apologii do heksaemeronu - lecz szybko przechodzi przez biblijne opisy stworzenia elementów natury i zwierząt, aby zatrzymać się na głównym stworzeniu Bożym - na człowieku. W ten sposób nasz autor chce jednoznacznie

69 Iohannes Chrysostomus, In Genesim, ser. 1, 2, SCh 433, s. 150, ŹMT 45, s. 55.

70 Iohannes Chrysostomus, In Genesim, ser. 1, 2, SCh 433, s. 150, ŹMT 45, s. 55.

71 Iohannes Chrysostomus, In Genesim, ser. 1, 2, SCh 433, s. 152, ŹMT 45, s. 55.

72 Por. Iohannes Chrysostomus, In Genesim, ser. 8, 1, SCh 433, s. 350.

73 Por. Włodarczyk, Rola synkatabasis, s. 250; Krupp, Shepherding the Flock of God, s. 72 .

74 Również w innych kazaniach Chryzostom dość często nawiązuje do dzieła stworzenia i przedstawia Boga jako Stwórcę, przez co wyraźnie podkreśla znaczenie tego elementu w swoim nauczania.

75 Szerzej zob. Por. M. Alexandre, Le Commencement du livre Genèse I-V. La version grecque de la Septante et sa réception, [Christianisme antique 3], Paris 1988. 
podkreślić zasadniczą orientację wszystkich stworzeń, które zostały uczynione ze względu na człowieka. Innymi słowy, celem Antiocheńczyka jest podkreślenie sensu aktów stwórczych, dokonanych przez Boga w ciągu pierwszych pięciu dni, których celem było przygotowanie właściwego „środowiska” dla istoty stworzonej szóstego dnia - dla człowieka. W ten sposób złotousty kaznodzieja pragnie ukazać człowieka jako adresata i odbiorcę bytów stworzonych wcześniej. W tym kontekście stworzenie wszechświata jawi się jako początek Bożego planu zbawienia człowieka. Nietrudno zatem zauważyć, że w dywagacjach Chryzostoma na temat dzieła stworzenia na pierwszy plan wysuwa się jego antropocentryzm ${ }^{76}$.

W kolejności stwarzanych przez Boga elementów natury Jan Chryzostom dostrzega Jego wszechmoc. Nawiązując do pierwszego zdania Księgi Rodzaju: „Na początku Bóg stworzył niebo i ziemię” (Rdz 1, 1) zauważa, że kolejność aktów stwórczych Boga nie odpowiada porządkowi:

Dlaczego tak? Najpierw uczynił niebo, potem ziemię? Najpierw dach, potem fundament? Bo nie podlega konieczności natury i nie jest zależny od kolejności wytwarzania ${ }^{77}$.

Zatem Bóg nie jest ograniczony żadnym porządkiem, ani żadną logiką, co więcej, przekraczanie zasad porządku i praw logiki stanowi - według Antiocheńczyka - dodatkowy dowód Jego niezwykłej mocy.

Odpowiadając na pytanie: dlaczego Bóg nie stworzył człowieka na początku lecz na samym końcu - w ostatnim dniu trwającego sześć dni dzieła stworzenia - i przez to przyznał mu ostatnie miejsce?, złotousty kaznodzieja odwołuje się do obrazów zaczerpniętych z życia codziennego, nawiązujących do zwyczajów panujących w Imperium Romanum ${ }^{78}$, które w sposób przejrzysty uzasadniały i wyjaśniały taki stan rzeczy. Przykładowo, odnosi się do ceremonii związanej z przybyciem władcy do jakiegoś miasta i przemarszem dworu cesarskiego, co wzbudzało wśród ludności powszechne zainteresowanie i podziw:

76 Por. Brottier, La lecture chrysostomienne, s. 23.

77 Iohannes Chrysostomus, In Genesim, ser. 1, 3, SCh 433, s. 166, ŹMT 45, s. 58. Dla zrozumienia tej wypowiedzi Antiocheńczyka niezbędne jest uwzględnienie antycznego obrazu świata. Człowiek żyjący w starożytności postrzegał ziemię jako płytę unoszącą się na wodzie, nad którą rozciągało się, w różnych warstwach, niebo z gwiazdami, które ze wszystkich stron też było otoczone wodami.

78 Por. Brottier, L’appel des «demi-chrétiens», s. 141-186. Podobne motywy pojawiają się np. u Filona Aleksandryjskiego (De opificio mundi 77-88), Grzegorza z Nyssy (De opificio hominis 2), czy Seweriana z Gabala (De mundi creatione 4, 5). 
«Jakże jednak - powiada - skoro [człowiek] jest cenniejszy niż cały świat, zostaje powołany do istnienia na świecie jako ostatni w kolejności?» Właśnie dlatego, że jest cenniejszy niż świat. Podobnie jak wtedy, gdy król ma wkroczyć w tryumfalnym pochodzie: generałowie i prefekci oraz żołnierze straży przybocznej oraz wszyscy niewolnicy idą na przedzie, aby - przygotowawszy pałac królewski i zapewniwszy wszelkie inne posługi - z wielką czcią podjąć króla, tak jest i w tym przypadku: króla, który ma być wprowadzony, poprzedziło słońce, prześcigło niebo, poszło przodem światło, wszystko zaistniało i zostało zapewnione, i dopiero wówczas człowiek, jako ostatni, z wielką czcią zostaje wprowadzony ${ }^{79}$.

Zatem stworzenie człowieka w ostatnim - szóstym dniu dzieła stworzenia, jest wyjaśniane przez Chryzostoma w duchu jego antropocentryzmu. Ten sam motyw pojawia się też w innych homiliach na Księgę Rodzaju ${ }^{80}$. Dlatego złotousty kaznodzieja podkreśla, że człowiek znajduje się w centrum stworzenia, co wyraża przez częste powtarzanie, że wszystko zostało uczynione „dla niego” (lub, gdy bezpośrednio zwraca się do słuchacza, mówi „dla ciebie”).

79 Iohannes Chrysostomus, In Genesim, ser. 2, 1, SCh 433, s. 186-187, ŹMT 45, s. 64. Por. tenże, In Genesim, hom. 8, 2, PG 53, 71.

80 Przykładowo, w homilii 7. z dłuższej serii, nasz autor prezentuje dzieło stworzenia jako etap przygotowawczy do stworzenia człowieka. Widzialny świat jest przedstawiany przez niego jako przepiękny pałac królewski, w którym jest przygotowana uczta, w której ma uczestniczyć stworzony człowiek - pan i władca stworzonego świata: „Abyś zaś zrozumiał przewyższającą wszystko miłość Pana do człowieka, którą okazuje wobec naszego rodzaju, rozpostarł niebo, rozciągnął ziemię, ukształtował firmament - jakby środkową ścianę oddzielającą stworzone wody; następnie nakazał, aby wody połączyły się i nazwał je morzem, zaś suchą ziemię wynurzył z głębiny i później ozdobił nasionami i innymi roślinami. Następnie przystąpił do stworzenia dwóch wielkich świateł i różnorodnych gwiazd, przez które pięknie ozdobił niebo. Później zaś, po stworzeniu istot żywych żyjących w wodach i ptaków latających powyżej ziemi na sklepieniu nieba - co zostało dokonane w ciągu pięciu dni - ponieważ trzeba było stworzyć także zwierzęta lądowe, rozkazał, aby i one powstały: jedne, które nadają się do jedzenia, inne, które są przydatne do służby, także dzikie zwierzęta i gady, wtedy - gdy przyozdobił wszystko pozostałe - jeszcze nadał układ i harmonijny porządek widzialnemu światu, i przygotował obfity stół, zastawiony różnymi potrawami wszelkiego rodzaju, zaopatrzony bardzo hojnie i w wielkiej obfitości, i - jakby to można powiedzieć - rozjaśnił pałac królewski ze wszystkich stron - z góry i z dołu - na różne sposoby, wówczas po wszystkim, ukształtował tego, który tym wszystkim powinien się rozkoszować, i któremu dał władzę nad całym widzialnym światem” (Iohannes Chrysostomus, In Genesim, hom. 7, 6, PG 53, 67-68, przekład własny). 


\section{Podsumowanie}

Powyższe analizy jednoznacznie wykazały, że Jan Chryzostom w rozważaniach na temat stworzonego świata zmierza do uwypuklenia hierarchii bytów i porządku istniejącego w otaczającej człowieka rzeczywistości. Akcentuje, że w zamyśle Boga trzeba dostrzec troskę o usytuowanie Jego aktów stwórczych w podwójnej perspektywie. Dlatego Antiocheńczyk, podkreśla że: 1) heksaemeron jest wyraźnie podzielony na dwie części, a stwórcze prace Boga dokonane $\mathrm{w}$ ciągu pierwszych pięciu dni są całkowicie podporządkowane Jego dziełu stworzonemu w dniu szóstym - człowiekowi;2) prace dokonane w ciągu pierwszych pięciu dni są pierwszym etapem historii zbawienia ${ }^{81}$, a jej ukoronowaniem jest Odkupienie człowieka.

Dzieło stworzenia traktowane jest przez Chryzostoma jako „katecheza” skierowana do każdego człowieka, niezależnie od jego statusu społecznego i poziomu intelektualnego, w tym celu, aby w wielkości i pięknie stworzonego świata odkrył Bożą potęgę i moc. Antiocheńczyk podkreśla, że - w drodze do Boga - podziw człowieka dla stworzonego świata jest etapem koniecznym, lecz samym w sobie niewystarczającym, jeśli nie prowadzi do poznania i kontemplacji Stwórcy; co więcej, może być nawet bezbożnością, jeśli powoduje odejście od Stwórcy oraz prowadzi do ubóstwienia elementów natury. W tym kontekście złotousty kaznodzieja zauważa, że Bóg pragnie ustrzec człowieka przed niewłaściwym odczytaniem przesłania płynącego z obserwacji działa stworzenia, które jako wspaniałe i godne podziwu objawia Bożą moc i chwałę, zaś jako niedoskonałe, nie pozwala na skłonienie się ku bałwochwalstwu. W homiliach na Księgę Rodzaju Chryzostom akcentuje też troskę i łaskawość Boga, który "zniża się" do człowieka i „dostosowuje” do jego mentalności.

Należy też zauważyć, że Antiocheńczyka prawie wcale nie interesuje kosmogonia. Jest to spowodowane chęcią skoncentrowania się na zaprezentowaniu dwóch naczelnych tematów: 1) związku między dziełem stworzenia i dziełem Odkupienia, co wyraża przez umieszczenie człowieka w centrum ekonomii zbawienia; oraz 2) związku między człowiekiem i jego Stwórcą realizującego się za pośrednictwem stworzonego wszechświata, którego cechy (zwłaszcza wspaniałość oraz niedoskonałości) są podporządkowane zbawieniu człowieka. Zatem antropocentryzm Chryzostoma i jego koncepcja historii zbawienia daje odbiorcom jego homilii na temat Księgi Rodzaju klucz do właściwego odczytania Pisma Świętego, którym jest nie tyle zrozumienie szczegółów biblijnych opisów, co przeżycie autentycznego spotkania z Bogiem.

81 Por. Brottier, La lecture chrysostomienne, s. 24-25. 


\section{Summary}

The paper presents John Chrysostom's discussion of the work of creation in his Homilies on Genesis (ed. L. Brottier, SCh 433). The analysis of his statements shows that in his considerations he tends to emphasise the hierarchy of existences and existing order in the reality which surrounds a human being. The work of creation is treated by this Antiochene as 'catechesis' directed to every man so he would discover God's might and power in the magnitude and beauty of the created world. In the analysed homilies Chrysostom stresses also God's care and kindness towards an individual. God expresses His care in 'condescending' and 'adapting' to human mentality in order to mercifully seek a man and redeem him. All analyses included in this paper lead us towards an unequivocal conclusion that in Chrysostom's discussion of the work of creation his anthropocentrism is crucial. 